\title{
Effectiveness of Power Point Media in 4 Seasons as the Sakura Culture Festival
}

\author{
Meidy Wollah, Nesti Liuw \\ State Polytechnic of Manado, Mapanget, Indonesia \\ Email: meidywollah73@gmail.com
}

How to cite this paper: Wollah, M. and Liuw, N. (2019) Effectiveness of Power Point Media in 4 Seasons as the Sakura Culture Festival. Open Journal of Social Sciences, 7, 262-274. https://doi.org/10.4236/jss.2019.78018

Received: July 23, 2019

Accepted: August 18, 2019

Published: August 21, 2019

Copyright $\odot 2019$ by author(s) and Scientific Research Publishing Inc. This work is licensed under the Creative Commons Attribution International License (CC BY 4.0).

http://creativecommons.org/licenses/by/4.0/ (c) (i) Open Access

\begin{abstract}
Culture festival of the cherry country or what is called the "Matsuri" has many and varied, that is why in every place in Japan has its own cultural festival. The Japanese cultural festival has high values for its visitors or we can conclude that the Japanese cultural festival is an activity of exchange of values to uphold the customs of their existence. Japanese cultural festivals follow the 4 seasons in Japan, namely spring (haru), summer (natsu), autumn (aki) and winter (fuyu). These 4 seasons are a technology for Japanese people and are very influential in their cultural festivals. Many festivals occur and follow the 4 seasons in Japan, and the most interesting, with the emergence of the most popular festivals, and only occur every season, namely the spring festival hanami (haru), the summer festival tanabata (natsu), momiji festival in the autumn (aki) and Sapporo festival in winter (fuyu). In this research, researchers will discuss Japanese culture festivals that affect 4 seasons in Japan. Where the researchers will introduce it through existing power point slide media. In this research, the effectiveness of power point slide media in 4 seasons as Sakura's cultural festival, will use qualitative research methods, namely a contextual study that makes humans as instruments, and adapted to a reasonable situation in relation to data collection which is generally qualitative. This research took place at the Manado State Polytechnic Department of Business Administration. Sources of data are primary, namely data taken directly at the student. While secondary data is a literature study and Japanese language curriculum. Data collection techniques are observation and research questionnaire. The data analysis technique is an effort to systematically search and organize the results of observations and dissemination of questionnaires to improve researchers' understanding of the findings based on the problems studied. The results of this study are research instruments in the form of questionnaires with 9 questions, 3 options given $1-3$ and number of respondents 143 people. Each item gets the highest score, and the result $=3 \times 9 \times$ $143=3861$. For the highest score that is $=3$, with the number of items $=9$
\end{abstract}


and the number of respondents $=143$. The total score of the answers from 143 respondents is $=3264$. Thus it can be seen the percentage value according to the perception of 143 respondents is $=3264: 3861 \times 100=84.5 \%$. From the results of data processing with each question, with the number of respondents 143, declared valid. This research aims to enable students to recognize Japanese characters, students can get to know Japanese customs; students can get to know Japanese culture and what Japan is like. Students can get to know the cultural festival at 4 seasons in Japan through an existing learning media, namely power point media. The students are not only taught Japanese language education, but get an introduction to Japanese culture.

\section{Keywords}

Powerpoint Media, 4 Seasons, Cultural Festival

\section{Introduction}

The festival in Japan known as "Matsuri" is a culture of folk parties or happy weekends in a series of memorials of historic events. Traditionally in ancient times, festivals were Japanese culture which was worship of ancestors and gods. Various cultural festivals are held throughout the year in various places in Japan. And the cultural festival in Japan is also a prayer reading carried out by their religious leaders, and is also a way to revive the regional economy [1]. Cultural festivals are also held with the intention of praying for success, success and safety for individuals, groups and communities. So, the cultural festival that is carried out, has a relationship that is very closely related to their lives [1] [2] [3].

To enliven the Japanese cultural festival in Indonesia, called "Bunkasai", as in the program of The Japan Foundation in Indonesia, it has been held in Indonesia, at universities, schools, even in companies in Indonesia [4]. At the Manado State Polytechnic itself, it also enlivened the festival of Japanese culture. Examples include traditional Japanese dances, traditional Japanese clothing, Japanese paper folding arts, Japanese flower arranging arts and showcasing tourist attractions as well as seasons in Japan and others. By presenting diverse cultural festivals, Japan also has many very interesting tourism spots.

Judging from the climate, Japan has 4 seasons that occur, these seasons are spring (Haru), summer (Natsu), autumn (Aki) and winter (Fuyu). These 4 seasons greatly affect Japan [5] [6]. Every season has its own cultural festival. This cultural festival is very influential and follows 4 seasons in Japan. "Most of the celebrations and festivals are held in season" (Kodansha Encyclopedia of Japan, 1993: 36) [7]. And this research, has discussed the festival of Japanese culture that affects 4 seasons in Japan. Because at this moments, many Japanese sympathizers are interested in the changing seasons in Japan, even children are easy like students, as well as Japanese teachers and people like to follow Japanese traditions, for example in terms of manga, anime, food, clothing, dance, models 
Japan as well as science and technology obtained from Japan [4] [8]. Another reason too, because this research is in accordance with the Japanese Language Education field where researchers will introduce it through existing power point slide media [9] [10] [11] [12].

The 4 seasons in Japan are spring (haru), summer (natsu), autumn (aki) and winter (fuyu), is a technology for Japanese society and the Japanese cultural festival [5] [6]. And it turns out there are the most popular festivals and only occur every season. In this research, about the Effectiveness Of Slide Power Point Media In 4 Seasons As Sakura's Cultural Festival. The research place in the Manado State Polytechnic Business Administration Department. Early the research, researchers prepare computers and LCD and are also assisted with textbooks and other tools. And then, preparing power point media for preparation of slides in teaching that will be displayed on the monitor. According to Ryo (2010: 43) "Power point is one of the special program packages in Microsoft Professional that is used to design presentation slides" [10]. And it is equipped with color and animation to make it more interesting to see. The reason the researchers made this research, because so far the students who have learned Japanese have not analyzed the cultural festivals in Japan. Therefore, this research has helped students in the introduction of Japanese cultural festivals. Besides they learn about Japanese language education, they can also find out about Japanese cultural festivals [2] [3].

The Japanese cultural festival that has been displayed on power point media is very good and useful for the introduction of cultural festivals. The students have got a new model/method [9] [11] [13]. This research uses qualitative research methods, namely a contextual research that makes humans as instruments, and adapted to a reasonable situation in relation to data collection which is generally qualitative. Data collection techniques the author will conduct observations, while the data analysis technique, the author will enter the field to obtain data from the distribution of Kueisoner. The purposes of this research are, design and create 4 season power point media programs as a festival of Japanese culture. Linking the cultural festivals in 4 seasons that occur in Japan identify the benefits of a power point media program.

\section{Theoretical Review}

In 1 year, the country of Japan, known as the country of Sakura, there are 4 seasons. Season, namely Spring (はる), Summer (なつ), Autumn (あき), and Winter (ふゆ). Every season has special characteristics with different customs. The first of spring, March to May, where Sakura flowers grow as a characteristic of Japan. Cold temperatures begin to decrease and warm up. The spring is the time of rebirth for nature in Japan. According to CukYuwana (2010), say that "Sakura can be approved as a spring symbol in Japan, because around the middle of March until the end of April is the hanami season" [7]. This season is also very much awaited to relax under the sakura flower trees [11]. Both family and 
friends, brothers and sisters, really enjoy the beauty of the cherry blossoms while carrying lunch, singing sitting relaxed under the sakurafolower trees. This moment is called "Hanami". According to CukYuwana (2010), States that "Until now Hanami became a habit in all Japanese society. Even it has been accepted as one of the characteristics of the nation's customs' [7].

The second, summer, from June to August. This season, when the rain comes, is called "Tsuyu". The end of the rainy season, the air temperature is getting hotter. Many dried leaves. The summer is also the time to plant rice, and it's time for all Japanese countries to experience green plants. This season also Japan celebrates the Tanabata festival. According to CukYuwana (2010), States that "There are several celebrations this season, one of which is famous is tanabata" [7]. The third, autumn in September to November. This fall, the characteristic of the leaves, the trees that change color bright red, gold, copper, and yellow. The leaves adorn the hills and mountains like carpet. Autumn is also called the romantic season and Japan celebrates the momiji festival. According to K. Ishii (2010), States that "The hydrangea and autumn leaves festivals attract many visitors too" [14].

The fourth, winter is entering December until February. The air temperature gets colder and cooler. Where the Japanese state is filled with white color. A distinctive feature in the winter season is the heavy snowfall. Many people enjoy statues and snow dolls when snow falls and becomes ice. This season is also waiting for people to play sky. And there is a festival that is celebrated by Japanese people, the Sapporo festival. According to T. Reinasari (2013), States that "In the winter in Japan there are various kinds of winter festivals. Among these winter festivals is Sapporo Yuki Matsuri. This festival attracts many visitors both from Japan and from outside Japan every year. One of the famous events from Sapporo Yuki Matsuri is an international snow sculpture contest which is attended by several teams from various countries [15].

Cultural festivals in Japan show the character of the people who are very guarding tradition. Both old and easy really enjoy various festivals in Japan with the celebrations. The establishment of a cultural festival in Japan, supported by Japanese people who are believed to have good artistic creativity. According to Kuttia, 1996: 23 defines "culture as attitudes and beliefs, ways of thinking, behaving, and remembering together by members of the community" [13]. The Japanese society almost every day holds matsuri, and also, known as Festival, both related to religion and religious beliefs and rituals that are not related to their religion and beliefs. Organizing a cultural festival in Japan, which is to be a fun event, and the only chance every year by Japanese people to see what our lives are like it. This is also intended to enrich people's lives by increasing social interaction. In 1 year the sakura country has 4 seasons, called shiki, many festivals that follow the 4 seasons that occur in Japan, but there is one festival that is most popular in each season when the 4 seasons come.

Hanami Festival is the spring festival that is very popular and very popular is 
the Hanami festival (seeing cherry blossoms). Hanami is a Japanese tradition of enjoying the beauty of flowers. When other flowers appear blooming, there is one thing that is the characteristic of Japan, namely Sakura. Besides Mount Fuji, Sakura flowers symbolize Japan. The appearance of cherry blossoms is a symbol of happiness when spring arrives. Besides that Hanami is also a picnic to hold a mat for a dinner party, singing, relaxing, having fun under the cherry blossom trees [7] [11]. According to Uman, Wardhani (2017), States that "the Hanami Festival, a Japanese tradition of enjoying flowers, especially cherry blossoms. Japanese people flocked to picnics holding mats and sitting under cherry trees to rejoice together, drink sake, eat Japanese specialties, etc' [11]. Tanabata festival. This festival is many festivals are in the summer in Japan, but, Tanabata Festival is very popular for Japanese people. According to Nojiri (1973: 60) "Kind permission of the publisher. incorporated in the strong sense of Japanese consciousness implanted in the cultural celebration of Tanabata" [3]. Tanabata is a star festival or Tanabata Matsuri. The festival is celebrated lively by writing a request on tanzaku or on colorful paper and tied to bamboo leaves. The tradition of writing this request took place since the Edo period.

And then, the Momiji Festival, This festival is in the fall which is a momiji festival in Kawaguchiko where we can see trees that change color to red, yellow, gold, orange and other colors. Momiji can also be interpreted as a foliage festival. The yellowing reddish leaves and gold make this scene very beautiful and captivating. Momiji is also very good at night. This festival we can see trees that change color while looking at Mt. Fuji [1] [13]. According to Uman, Wardhani (2017) "This season is famous for its colorful leaves called Momiji [11]. And then, Sapporo snow Festival. This is an annual winter festival in Japan, which is held in the first week of February. At this festival there are a series of statues with their shapes and characters, and exhibited very large ice and snow carvings, including ice sculptures in the form of miniature famous buildings. And can see sculptures of ice that are shaped like rajah and famous people while eating. Or see the ice statue of a horse and princess prince. According to Reinasari (2013), states that "One of the famous events of Sapporo Yuki Matsuri is an international snow sculpture contest which was attended by several teams from various countries."[15]

Media Effectiveness of Power point is the microsoft power point provides slide facilities to accommodate the points of discussion that will be delivered to students. And it is helped by LCD. With the animation facility a slide can be interestingly modified. Accordingly to Mahanani (2013) States that "learning by using powerpoint is effective in improving students' skills in problem-solving". [9] The use of powerpoint media is practical and can be used for all paper sizes, has a variety of presentation techniques with various color combinations or animations, can be used repeatedly, healthier than using a blackboard and OHP. Muharoma (2014) Statesthat "learning by using powerpoint media canimprove the quality of learning". [9] The Power point is more effective for Japanese learning. According to Mulyasa (2004: 48) defines that "learning resources can 
be formulated as everything that can provide convenience to students in obtaining some information" [13]. The power point media can also help presentations, which are usually used to explain things that are summarized and packaged in a power point slide [10]. So that readers can more easily understand our explanation through visualization summarized in the slide.

\section{Research Methodology}

This research was conducted from April, May and June 2019 at Manado State Polytechnic Department of Business Administration. Then this research was conducted in 5 classes with the number of respondents 143.By filling the questionnaire on 9 questions. Sources of data in this study are primary data and secondary data. Primary data source where data will be taken directly to all students involved in this research. Secondary data sources are taken from library studies, and Japanese language curriculum. Implementation of learning with Technology-based Japanese Language Teaching that leads to Japanese culture using power point media technology. In this research, the method used is a qualitative method. Data collection is done by distributing questionnaires, and observations. Data analysis is an effort to systematically search and organize records of observations, and dissemination of questionnaires, to improve researchers' understanding of findings relating to the findings discussed. Data analysis is a process of sequencing data, organizing into a pattern, categories and basic sequence units. To achieve the total score in this research, the data used is measurement of reliability which is the level of stability of a measuring instrument, measurement of validity is a measure that shows the level of reliability of an instrument. and the results of the correlation which are the criteria used to determine the level of the relationship that occurs between variables. Then the results of processing the data used are SPSS 2019.

Applications as a result of Media Power Point effectiveness in 4 seasons as Japan's cultural festival. The some of the stages carried out in the conduct of this research activity are power point media presentations that are teaching. The first starts with the preparation steps of the needs and objectives, sets the learning objectives. And then, prepare power point media to be presented in qualitative methods. For data collecting, researchers conducted observations and disseminated questionnaires to student learning outcomes. And then, the power point media displays that have been presented as follows.

Picture Explanation:

1) Picture 1: The beginning of the image display.

2) Picture 2 is the spring festival of Japan that is very popular and very popular is the Hanami festival (seeing cherry blossoms). Hanami is a Japanese tradition of enjoying the beauty of flowers. When other flowers are blooming, there is one thing that is characteristic of the Japanese country is Sakura. Besides Mount Fuji, Sakura flowers symbolize of Japan. The appearance of cherry blossoms is a symbol of happiness when spring arrives. Besides that, Hanami is also a picnic to hold a mat for a dinner party, singing, relaxing, having fun under the cherry blossoms. 


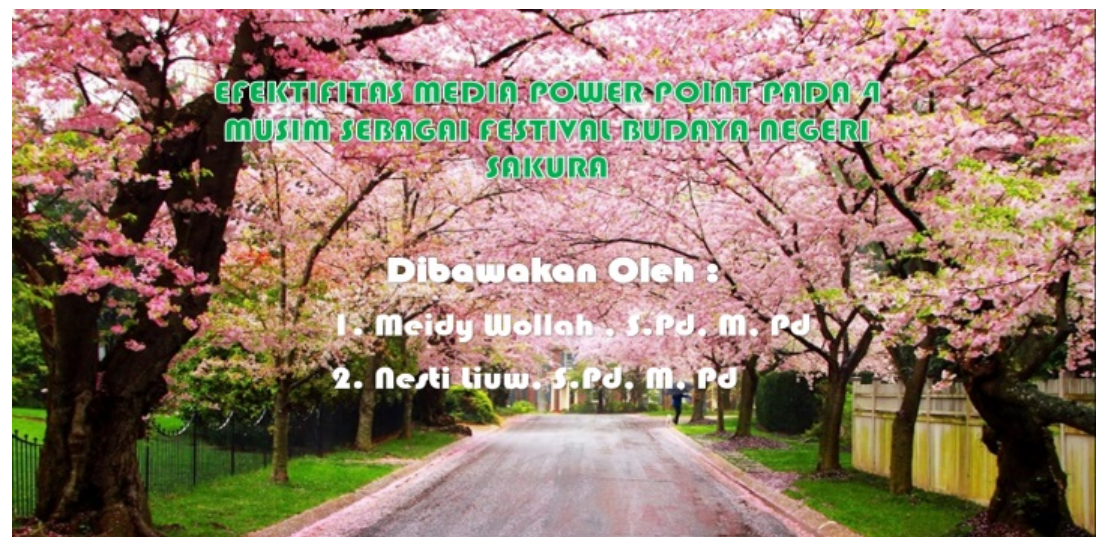

Picture 1. The beginning of the display.

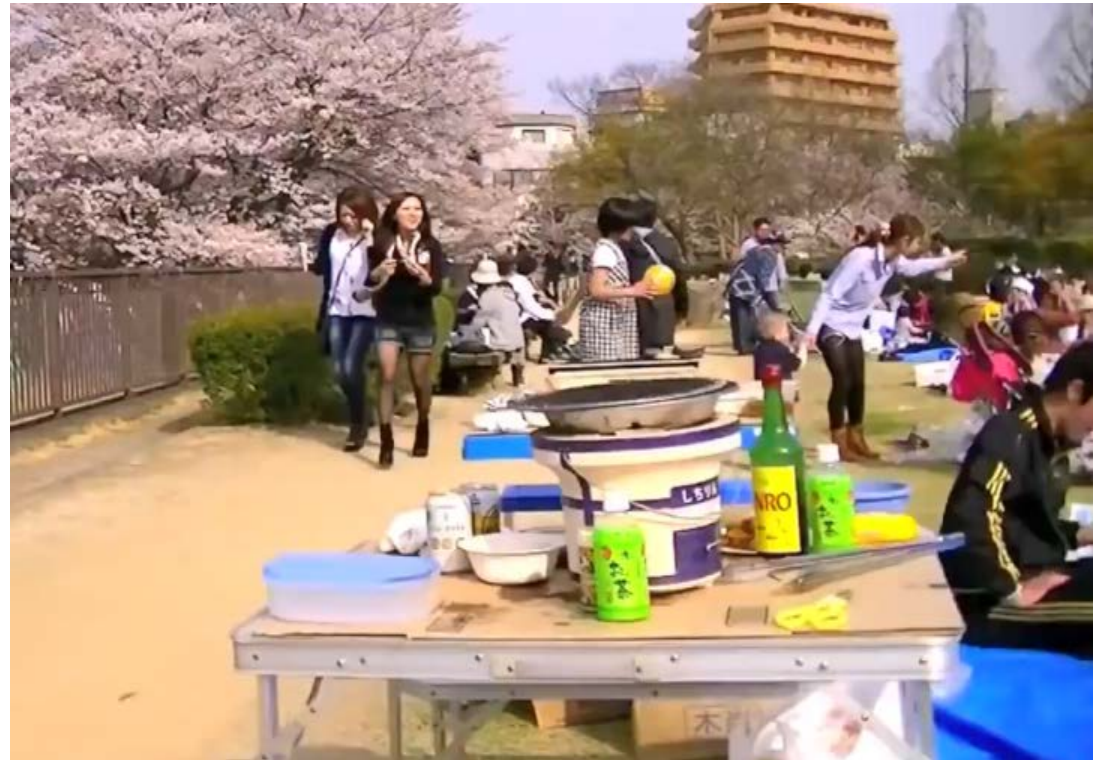

Picture 2. Hanami festival.

3) Picture 3 is Tanabata festival which is very popular for Japanese people. Tanabata is a star festival or Tanabata Matsuri. The festival is celebrated lively by writing a request on tanzaku or on colorful paper and tied to bamboo leaves. The tradition of writing this request took place since the Edo period.

4) Picture 4 is momiji festival Kawaguchiko. Where we can see trees that change color to red, yellow, gold, orange and other colors. Momiji can also be interpreted as a foliage festival. Yellowing, reddish and golden leaves make this scene very beautiful and captivating. Momiji is also very good at night because this festival we can see trees that change color while looking at Mt. Fuji.

5) Picture 5 is Sapporo Festival is the winter festival in Japan. Held in the first week of February. At this festival there are a series of statues with their shapes and characters, and exhibited very large ice and snow carvings, including ice sculptures in the form of miniature famous buildings. And can see sculptures of ice that are shaped like giant and famous people while eating. Or see the ice statue of a horse and princess prince. 


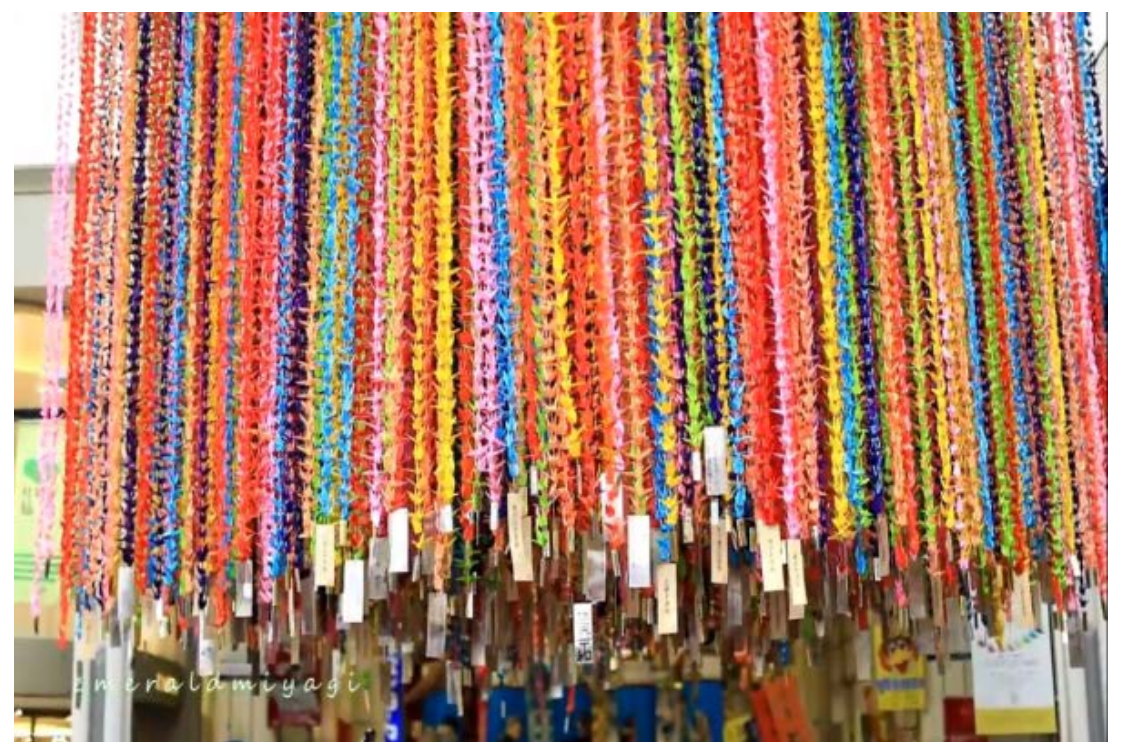

Picture 3. Tanabata festival.

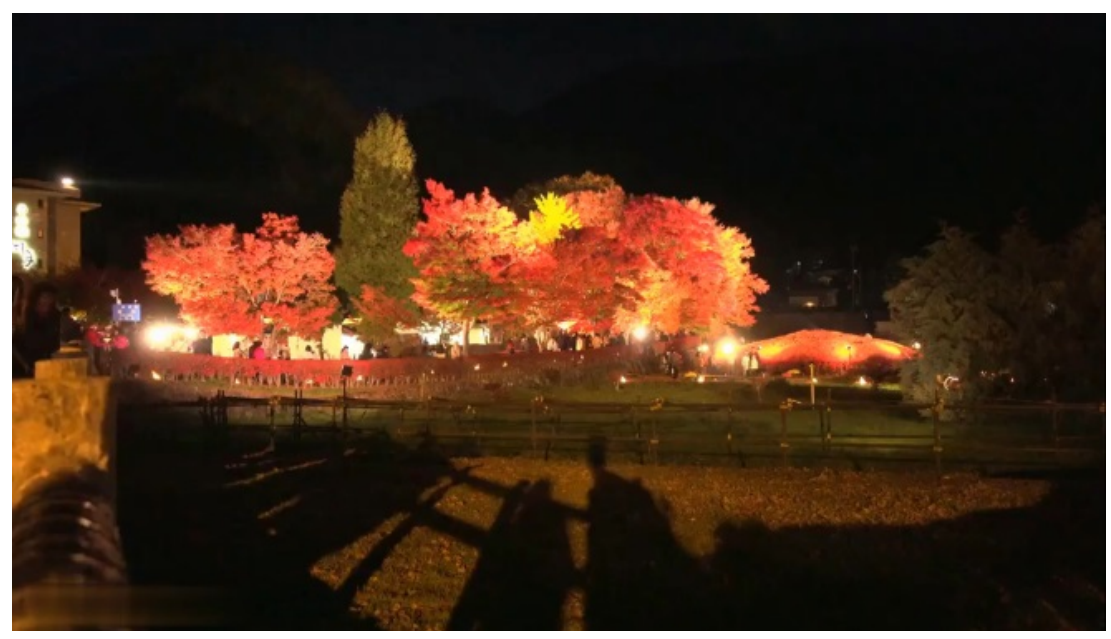

Picture 4. Momiji Festival Kawaguchiko.

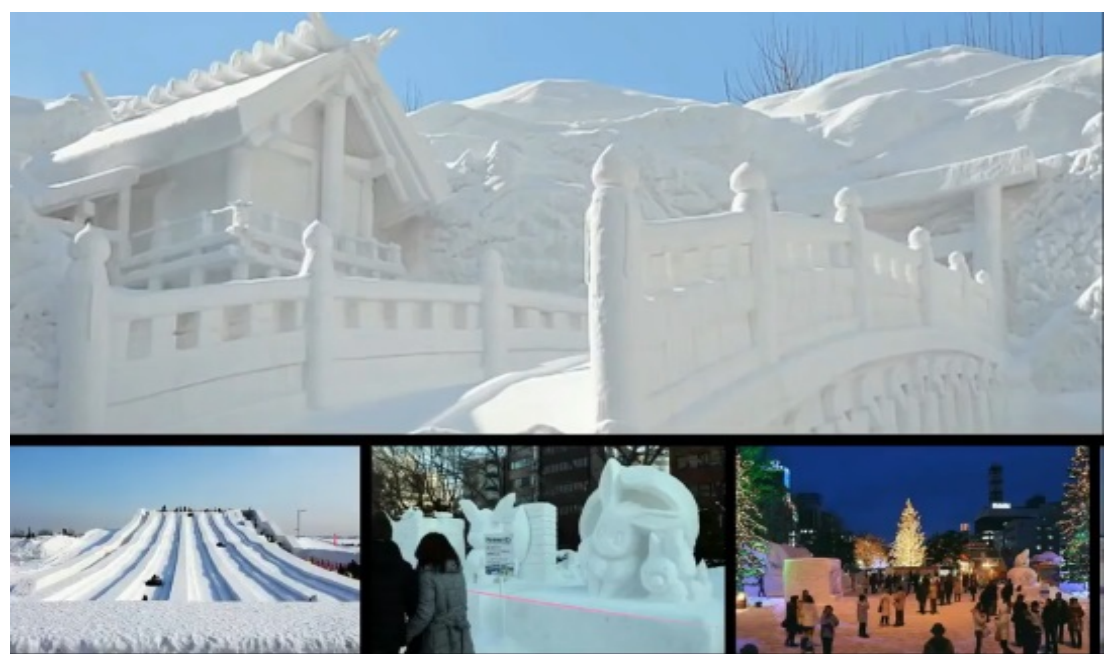

Picture 5. Sapporo festival. 


\section{Discussion and Result}

The Japanese language education at the Manado State Polytechnic at the Department of Business Administration. Students get Japanese language education where students can master sentence forms, sentence patterns and deepen conversations taught in accordance with the field being taught. In addition to getting a Japanese language teaching education, the instructor gave an introduction to Japanese culture. Students are not only taught material about vocabulary, sentence patterns, and conversations in Japanese, but also Japanese culture. The researchers have presented the results of our research, namely "The effectiveness of power point media in 4 seasons as a sakura country culture festival" through power point media to introduce Japanese cultural festivals and obtain accurate data. And then, the tests that have been carried out through the distribution of cookies, include 9 statements, to students, and obtain the following results:

\section{Total Score}

The research instrument was a questionnaire with 9 statements with 3 options given. Score $1-3$, and the number of respondents was 143 people. If each item gets the highest score, the result is $3 \times 9 \times 143=3861$. For the highest score $=3$, with the number of items $=9$ and the number of respondents $=143$. The total score of the answers from 143 respondents totaled $=3264$. Thus it can be seen the percentage value according to the perception of 143 respondents $=3264: 3861 \times$ $100=84.5 \%$ based on respondents' answers. This can be made in the data distribution category in the following forms (Figure 1).

The total score to approve $=3264$ included in the "good" to "excellent" interval category. From the results of the analysis of the respondents' answers the score shows good value of $84.5 \%$.

\section{Measurement of Reliability}

Reliability is an index that shows the extent to which a measuring instrument is reliable or reliable. Reliability shows the consistency of a measuring instrument in measuring the same symptoms. Instruments are declared reliable, if the instrument is used to measure the same object/subject by the same or different people at different times, it will produce relatively the same data. Reliability is the level of stability of a measuring instrument. A measuring instrument is said to be steady if in measuring something repeatedly, the measuring instrument gives the same results. Of course with the condition that the conditions when the measurement does not change. Reliability means reliable (dependability) and the results can be predicted (predictability).

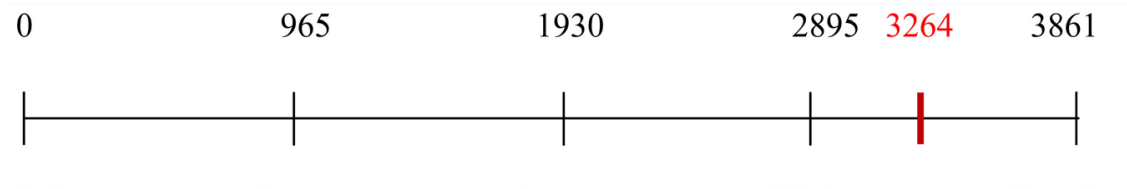

Fail Low Hoderate High Excellent

Figure 1. Total score. 
Reliability shows the level of accuracy. If you want to test the accuracy of a measurement result, the size obtained is the correct measure of something you want to measure.

Acording to Sugiono (2016), States that "The reliability test of the measuring instrument in this study used the Cronbach a (alpha) coefficient. The instrument (questionnaire) of the study is said to have moderate reliability if the value of $\alpha$ from Cronbach's is between 0.5 to 0.6 and an instrument is declared reliable if the reliability coefficient is at least 0.6 ". The reliability test of this study can be explained as follows (Table 1 ).

From Table 1, it can be explained that the instrument or statement has a reliability or reasonable coefficient to be used as a measurement tool in research. Where the criteria for a research instrument are said to be reliable if the alpha value is $>0.6$. In the table shows that the reliability coefficient is greater than 0.6 , which is 0.752 and this means the instrument is declared reliable.

\section{Measurement of Validity}

Data validity is a measure that shows the level of compatibility of an instrument. Legitimate instruments have high validity.Instruments are said to be valid if they are able to measure what is desired, able to reveal data from variables that are examined appropriately, the high and low validity of the instrument shows the extent to which the data collected does not deviate from the description of the intended validity. The work step to find out whether the instrument is valid or not is, 1) distributing instruments that will be tested for validity to the speakers, 2) collecting data on the results of instrument trials, 3) check data completeness, 4) make a helper table to place the scores on the items obtained, to facilitate the calculation or processing of the following data, 5) calculate the validity coefficient by using the product moment correlation coefficient symbolized by the value of $r$ for each item, 6) compare the $r$ value of the calculated result with the $r$ value in table $r$ available. If the value of $r$ count $>r$ table, the research instrument is said to be valid.

For clear validity in this study, the validity coefficients of each item can be seen as follows (Table 2).

Based on the Table 2, to measure the value of instrument validity determined by looking at the value of $\alpha=0.05$ with the number of respondents 143 respondents so that the value of $\mathrm{r}(0.05,143)$ on the Product Moment Table and the value of $r=0.163$. If the results of validity are above 0.163 then the instrument is considered valid.

\section{Correlation Results}

The criteria used to determine the level of the relationship that occurs between variables as follows (Table 3 ).

Table 1. Reliability test table.

\begin{tabular}{cc}
\hline Cronbach's Alpha & N of Items \\
\hline 0.752 & 9 \\
\hline
\end{tabular}

Source: Processed Results of 2019 SPSS Data. 
The results of the correlation analysis of the instruments used in this study can be seen in the Table 4 below.

From the results of data processing, each of the questions, with the number of respondents 143, is declared valid and for the clear validity of this study can be seen the validity coefficient on each item statement.

Table 2. Test validity table.

\begin{tabular}{cccccc}
\hline & Nun & Stat. Product Moment (r) & Validity & N & Information \\
\hline 1 & Statement Answer 1 & 0.163 & 0.465 & 143 & VALID \\
2 & Statement Answer 2 & 0.163 & 0.470 & 143 & VALID \\
3 & Statement Answer3 & 0.163 & 0.502 & 143 & VALID \\
4 & Statement Answer4 & 0.163 & 0.680 & 143 & VALID \\
5 & Statement Answer5 & 0.163 & 0.650 & 143 & VALID \\
6 & Statement Answer6 & 0.163 & 0.582 & 143 & VALID \\
7 & Statement Answer7 & 0.163 & 0.574 & 143 & VALID \\
8 & Statement Answer8 & 0.163 & 0.638 & 143 & VALID \\
9 & Statement Answer9 & 0.163 & 0.638 & 143 & VALID \\
\hline
\end{tabular}

Source: Results of 2019 SPSS Data Processing.

Table 3. Of Guidelines for interpretation of correlation coefficients.

\begin{tabular}{cc}
\hline Coefficient Interval & Relationship Level \\
\hline $0.00-0.19$ & Fail \\
$0.20-0.39$ & Low \\
$0.40-0.59$ & Moderate \\
$0.60-0.79$ & High \\
$0.80-1.00$ & Excellent \\
\hline
\end{tabular}

Source: Business Research Methodology by Sugiono, 2016.

Table 4. Correlation table.

\begin{tabular}{cccc}
\hline No. & & Correlation coefficient & Relationship Level \\
\hline 1 & Statement Answer 1 & 0.465 & Moderate \\
2 & Statement Answer 2 & 0.470 & Moderate \\
3 & Statement Answer 3 & 0.502 & Moderate \\
4 & Statement Answer 4 & 0.680 & High \\
5 & Statement Answer 5 & 0.650 & High \\
6 & Statement Answer 6 & 0.582 & Moderate - High \\
7 & Statement Answer 7 & 0.574 & High \\
8 & Statement Answer 8 & 0.638 & High \\
9 & Statement Answer 9 & 0.638 & \\
\hline
\end{tabular}

Source: Results of 2019 SPSS Data Processing. 


\section{Conclusion}

Media power point is a computer program for presentations in terms of presentations for learning developed by Microsoft in the application package for learning. Microsoft power point provides slide facilities to accommodate the points of discussion that will be delivered to the learner, and is assisted with LCD, animation facilities for a slide, and can be modified interestingly. With the power point media, it can help and introduce cultural festivals in the 4 seasons in the country of cherry, in this case Japan. The students can know and understand the meaning of popular cultural festivals that occur in 4 seasons in Japan. These results can support Japanese Language Education in their own institutions and for learning Japanese in other institutions. And also, this research aims to enable students to recognize Japanese characters, students can get to know Japanese customs, students can get to know Japanese culture and what Japan is like. Students can get to know the cultural festival at 4 seasons in Japan through an existing learning media, namely power point media. From the results of data processing with each question, with the number of respondents 143, declared valid.

\section{Suggestion}

The use of power point media in the class for Japanese language learning, of course, also has limitations, so it is recommended that the use of this media be supported also by other learning resources. Then, it is recommended for further application development, in the development of later research. For further development it is recommended that you also be able to add products or applications with other models or different types of products in Japanese language teaching that are related to Japanese culture.

\section{Acknowledgements}

Thanks to Manado State Polytechnic for this research. And also, thanks for friends in the business administration department and my students.

\section{Conflicts of Interest}

The authors declare no conflicts of interest regarding the publication of this paper.

\section{References}

[1] Herniwati, H. (2011) Masyarakat Jepang Memaknai Matsuri Dalam Kehidupannya. Jurnal Kajian Kebahasaan.

[2] Rosliana, L. (2017). Wisata Budaya Sebagai Alat Penguat Negara Jepang.

[3] Renshaw, S.L. (2011) Celebration of Seasonally Based Holidays and Fastivals in Japan. A Study in Cultural Adaptations. Proceeding of the International Astronomical Union, 7, 308-314. https://doi.org/10.1017/S1743921311012749

[4] Nugraha, H. (2017) Upaya the Japan Foundation Dalam Meningkatkan Hubungan 
KerjaSama Indonesia Jepang Dibidang Budaya.

[5] Program Study Pendidikan Bahasa Jepang (2015) 4 Musim Di Jepang. http://www.pendidikanbahasajepang-unnes.com/2012/10/4-musim-di-jepang.html

[6] Sartika, R.D. (2017) Negara Kepulauan Jepang.

[7] Yuwana, C. (2010) Makna sakura bagi Masyarakat Jepang.

[8] Komarudin, R. and Noor, R.R. (2017) Analisis Perancangan Animasi Interaktif Mengenai Bahasa Jepan.

[9] Hasjiandito, A., Adiarti, W. and Wantoro (2015) Religious Topic: The Effectiveness of Learning Media Based on Powerpoint. Indonesian Journal of Early Childhood Education Studies, 4, 111-115.

[10] Septiyani, I.S. (2013) Efektivitas Metode Langsung Dengan Media Picture Power Point Dalam Pembelajaran Pola Kalimat. https://lib.unnes.ac.id/17231/

[11] http://www.ejournal.jak-stik.ac.id/index.php/komputasi/article/viewArticle/2215

[12] Meidy, W. and Anton, P.M. (2017) Efektifitas Penggunaan Multimedia Interaktif (Macromediaflas) Dalam Pembelajaran Hiragana Kakijun. Jurnal Pendidikan Bahasa Jepang ASPBJI Korwil Jabar, 11. http://repository.polimdo.ac.id/id/eprint/1663

[13] Lispridona, D. (2014) Pemanfaatan Sumber Belajar Untuk Meningkatkan Motivasi Pembelajaran Budaya. https://journal.unnes.ac.id/nju/index.php/lingua/article/view/2982

[14] Ishii, K. (2010) Fuji Kyuko and Tourism in Mt Fuji Area. Japan Railwail \& Transport Review, No. 55, 26-29.

[15] Reinasari, T. (2013) Yuki Matsuri Di Kota Sapporo. 